\title{
An exploration of taught master's student perceptions of UK dissertation supervision
}

\author{
Stephanos Anastasiadis * \\ School of Business and Management, Royal Holloway University of London, UK \\ Justin O'Brien \\ School of Business and Management, Royal Holloway University of London, UK \\ * Corresponding author
}

\section{Abstract}

This paper presents the results of an investigation into taught master's students' expectations and experience of being supervised during their final project. It does so using exploratory survey and focus group data from one UK institution with a high proportion of international students. The paper adds to the limited literature on master's students' experience and makes two further main contributions. It finds that students both expect supervisor engagement and respond well to it, and argues that focusing on key elements of the dyadic supervision process (supervisor availability and level of engagement, feedback provided, and provision of expert guidance on theory and method) can disproportionately improve students' overall learning and satisfaction. In addition to furthering knowledge in this area, the research suggests numerous practical implications and lines of potential future inquiry.

Keywords: taught master's; dissertation supervision; student perceptions; student experience, international students.

\section{Introduction}

Taught UK master's programmes typically last one year, in contrast to undergraduate and doctoral programmes, which take at least three years to 
complete. This means that universities have relatively little time to understand master's students, which may help to explain why the master's degree is 'one of the least understood or researched academic levels in higher education' (Drennan and Clarke, 2009, p.483). UK master's programmes have not been included in public evaluations of teaching quality, but this is changing with the metrics-driven evolution of higher education (Tomlinson, 2018), the Teaching Excellence Framework (TEF), (BIS, 2015; 2016) and the launching of the Office for Students (OfS), with its focus on student value-for-money (OfS, 2018).

The financial potency of business school master's degrees is already well known. In $2017 / 18$, UK business and management students accounted for $21 \%$ of the postgraduate taught student population (HESA, 2019), and many higher education institutions now depend on the income these students bring (Hordern, 2014). Moreover, $28 \%$ of the UK's postgraduate taught population $(126,000$ of 450,000$)$ in 2017/18 were non-EU students; these international students are often concentrated in highly multi-cultural business schools (HESA, 2019).

European and particularly UK master's students typically produce a substantial, independent piece of capstone work to complete their degree (Meeus et al., 2004). Described by Pilcher (2011, p.37) as a constantly-changing 'elusive chameleon,' the dissertation or final project (as it is called here) represents a significant opportunity for student learning and personal growth, as well as potentially influencing students' abiding memories of their institutions. Yet, 'little is known of coursework master's graduates' experience of research or research supervision' (Drennan and Clarke, 2009, p.483). Although much work has been done on PhD supervision, the master's level remains under-researched (Harwood and Petrić, 2018). In other words, not enough is known about master's students' experience of the final project, which forms a significant component of their learning. Indeed, Larivière et al. (2008) and Dietz et al. (2000) have challenged the usefulness in practice of dissertations, due to factors such as poor supervision, insufficient time, and students' limited analytical experience. There may well be a discrepancy between the potential benefits and students' lived experience.

This paper uses focus groups from two temporally distinct cohorts of MSc 
International Management students and an exploratory questionnaire administered to the first cohort of those students to provide insight into student expectations and experience of supervision at one anonymised institution, BusinessCollege, which has followed the traditional, dyadic supervision model of one-to-one supervision. At BusinessCollege, a supervisor is allocated 18 hours per MSc student, to cover guidance and marking, with a minimum requirement of at least two face-to-face meetings.

The rest of this paper proceeds as follows: the next section provides the theoretical basis for the research, through a review of the literature on supervising master's level student dissertations, and on student evaluation of teaching. The methodology section then outlines the use of focus groups and a questionnaire. The research findings and discussion sections follow subsequently. The paper concludes with reflections on the consequences of the findings for practice and scholarship.

\section{Literature Review}

This section provides an overview of two dimensions that are relevant to the student experience of supervision: factors relevant to successful supervision, and student evaluation of teaching. A search of the literature reveals that learning at master's level, and dissertation supervision in general, has until recently received limited attention. There is some contemporary research on master's level business/management teaching and learning, focussed on Master of Business Administration (MBA) programmes (e.g. Simpson et al., 2010; Beenen, 2013; Hordern, 2014; more generally, Hallett, 2010); other programmes receive less attention (Beatty and Leigh, (2010) speculate on the reasons). Literature on supervision, by contrast, tends to concentrate on the supervisor rather than the student, whether the focus be at master's (Anderson et al., 2006) or doctoral level (Halse and Malfroy, 2010; Halse, 2011; Morris et al., 2012).

\section{Supervising master's students}


According to Todd et al. (2004), the supervisor's challenge is to inculcate autonomous student learning whilst recognising that many supervisees are insufficiently prepared for this study format. Ebadi and Pourahmadi (2019) highlight different student-staff expectations of supervisory input as problematic, a finding shared by Roberts and Seaman (2018); simply put, students want supervisors to be more directive, rather than providers of general guidance. Filippou et al., (2017) find that international students expect more from their supervision than native students. Contradictorily, Pilcher (2011) posits that good students desire suggestions, whilst others request direction, linking supervisory approach to student quality.

Nonetheless, for master-level work, in which original, ground-breaking research is not expected, and in which the timeframe is significantly compressed, we can expect technical expertise to play a significant role. Vos and Armstrong (2019) argue that there is also a significant gap between supervisors' knowledge and student learning in the research methods classes. Critical incident research (Roberts and Seaman, 2018) highlights the undergraduate supervisor's role in confidence building and providing clear, direct advice. Reguant and colleagues (2018), however, emphasise the generic skills of fostering and growing student enthusiasm, whilst transferring an understanding of the research process. Moreover, different students may require different pedagogical approaches to the supervision of their final project (Harwood and Petrić, 2018). Dysthe's earlier (2002) study into supervisory roles identifies three kinds of supervisory model, each with its own dynamic; students can have different preferences and, given the highly diverse student population of master's students in the UK, it is reasonable to expect that they will.

Research into Arabic-speaking master's students studying with English as a foreign language highlights key learner skills gaps: limited research scoping, design and analysis experience, exacerbated by poor academic writing capability (Ebadi and Pourahmadi, 2019). Challenges can also be compounded by issues of learner isolation, low motivation and poor attendance (Vos and Armstrong, 2019). However, the literature is relatively silent on the question of factors important for successful dyadic master's-level supervision. By way of explanation, Pilcher (2011) emphasises the elusiveness of the terms 'master's dissertation' and 'master's supervision', a 
challenging situation that has been further augmented by an increasingly diverse student body. Nonetheless, some trends can be gleaned from the relatively scant research that has been conducted on master's dissertations, augmented with insight from doctoral and undergraduate supervision. One can identify five key factors: supervisor availability and level of engagement, feedback provided, and the provision of expert guidance on theory and method. It is to these that the paper now turns.

\section{Supervisor's availability and level of engagement}

Most extant work on master's student supervision has been in the context of the traditional dyadic supervisor-student model. One study (de Kleijn et al., 2014) addresses supervisor responsiveness and adaptability to students' needs and circumstances, and in their earlier research de Kleijn et al. (2012) uncovered two variables: affiliation and control. Affiliation captures 'the extent to which the supervisor is emotionally involved in the project and/or with the student', whilst control captures 'the extent to which the supervisor gives direction to the student activities' (de Kleijn et al., 2012, pp.926-927). Such research suggests that clear communication between supervisor and student is needed, as is matching the appropriate level of direction giving with the specific needs of the student. These findings are congruent with previous work by Unsworth and colleagues (2010) which highlights the importance of the relationship between supervisor and student.

Here, availability is a key theme. Some supervisors can allocate insufficient time for supervision (Pilcher, 2011; Ebadi and Pourahmadi, 2019), whilst others are unavailable during the summer term when master's students need their support most (Pilcher, 2011). Ebadi and Pourahmadi (2019) call for a code of practice to clarify bilateral duties and expectations. Parker-Jenkins's (2018) doctoral supervision research warns of the dangers of overstepping professional supervisory boundaries (over-engaged) and being a never-available jet-setting internationalist (underengaged). One can conceptualise availability as the supervisor's willingness to communicate with the student as needed, as a precursor to the level of engagement indicated. This is defined by the extent to which the supervisor achieves a balance 
between being over-involved with the student's work (overbearing), engaged (a student-defined optimum) and under-involved (effectively absent).

There is also evidence that personal and holistic supervision ${ }^{1}$ is particularly valuable for international students and those in soft disciplines (Egan et al., 2009; Khalifa, 2018), such as Management. Moreover, motivation is widely acknowledged to have an impact on learning in general, and on deep learning in particular (Naidoo, 2015). Final project supervisors in a dyadic supervision setup are well placed to stimulate student motivation, and can have a transformative impact through the learning environment they promote (Rowley and Slack, 2004). Conceptually, a supervisor's availability and level of engagement can be identified as two distinct factors.

\section{Providing Feedback}

Andrews and colleagues (2018) find that learner feedback is frequently a contentious topic in student satisfaction measurements. Where a supervisory role is poorly defined and understood, expectation mismatches around student support can occur, which can impact on student satisfaction metrics (Del Rio et al., 2017). Vos and Armstrong's (2019) research on Marketing dissertation supervision highlights the problem of students missing scheduled meetings and seeking feedback too close to the submission deadline.

However, when master's students receive dissertation feedback that they perceive as positive and as providing good guidance, they tend to perceive themselves to be learning from their supervisors (de Kleijn et al., 2013). Moreover, it is well established, generally, that feedback that is specific, timely, positive ('sugar coated' (Zheng et al., 2019)) and tailored to the student is a significant factor in student learning (see Petty, 2009; Paolini, 2015; Wiltbank et al., 2019).

\section{Expert guidance on theory and method}

Todd and colleagues (2004) identify academic expertise as one of a supervisor's main roles. However, in the context of large business school cohorts, master's

\footnotetext{
${ }^{1}$ That is, supervision that does not simply focus on the technical aspects of the task at hand. 
supervisors are not always experts in students' specific topics, a phenomenon Harwood and Petrić (2018, p.50) pithily summarise in a chapter title: "This is not my topic but I'Il help as much as possible". Vos and Armstrong (2019) highlight mismatched supervisors (assigned between 5 and 15 students) as their main challenge: many academics are required to cover topics where they have no in-depth knowledge. However, good quality feedback is particularly salient in the absence of an optimal student-supervisor subject expertise match (de Kleijn et al., 2014). A recent report (Dericks et al., 2019) suggests that supportiveness rather than specific expertise is more important, even for doctoral student satisfaction.

From the literature review, supervisor engagement, availability and feedback appear to be the most salient for successful dyadic master-level supervision. However, supervisors' specific methodological and theoretical competence are also significant factors, and are therefore included in the research design.

\section{Student evaluation of teaching}

Student evaluation of teaching quality is a fraught topic. On the one hand, as Remedios and Lieberman (2008, p.91) argue, teaching quality is 'by far the largest determinant of student evaluation of courses', a view supported by Gibson (2010) and by Douglas and colleagues (2006). These authors' views present an understandably positive image of teaching evaluation. There is robust evidence that student satisfaction and student learning are indeed strongly related (Douglas et al., 2006; Gibson, 2010). Ideally, therefore, an educator would simply concentrate on teaching.

On the other hand, however, there has also been growing disquiet in recent years at the over-reliance on student evaluation of teaching as a measure of teaching quality. Blackmore (2009) argues that generic teaching evaluations are more about accountability and marketing than improving teaching and learning. Billsberry (2014, p.151) was concerned enough by increasing managerialism and accountability to students, to address his final editorial to the topic. Moreover, a recent meta-study of 
students' evaluation of teaching suggests that evaluations are often unrelated to independent views of the quality of student learning (Uttl et al., 2017), supporting Blackmore's (2009) earlier argument. Zabaleta (2007) finds a link between low grades and low scores in student evaluations, but no significant link between higher grades and higher evaluations, suggesting that students may merely punish faculty awarding lower grades. More broadly, Clayson and colleagues (2006) find a clear reciprocal relationship between grades and students' evaluation of their teachers (see also Lancaster and Fanshawe, 2015). Metrics gamification appears to be a widespread and persistent phenomenon, and the authors bluntly conclude that, 'instructors can buy evaluations with grades', independent of learning (Clayson et al., 2006, p.64). Although the UK government acknowledged this danger when planning the TEF (BIS, 2016, p.12), Eaton and Penaluna's (2019) analysis shows sharp and unexplained UK university grade inflation, for which they blame the TEF.

Potentially exacerbating the challenges associated with relying on student evaluation of teaching is the changing role of the student. Numerous factors have conspired to position the student as a consumer (Finney and Finney, 2010) in the UK. These include a rise in tuition fees; the remit and actions of the Office for Students (Nicholls, 2019); the introduction of the Teaching Excellence Framework (Gunn, 2018); and of the weight given to student evaluations, particularly that of the annual National Student Survey (Holland, 2019). There is a danger, as Billsberry (2014, p.152) trenchantly argues, of edutainment, a 'particular distortion of education where the drive is to entertain students in educational settings rather than teach them'. This concern, that non-expert students may evaluate style more favourably than substance, is at least a generation old (Naftulin et al., 1973). It reflects the main message in Kruger and Dunning's (1999) seminal work on 'unrecognised incompetence' (see also Blackwood, 2012, p.72, on business undergraduates). That is, students are not always best placed to evaluate pedagogical or curriculum decisions, with the result that students may judge the teaching they have received by criteria such as grades received or the degree of support they perceive.

The foregoing discussion of factors influencing student evaluation of teaching suggests that the supervisor-supervisee relationship may be negatively impacted, 
precisely at the stage where students need to be working more independently. It is certainly possible to be sceptical of student evaluation, whilst recognising its central role. It is therefore desirable to find a way of teaching that minimises the disadvantages of student evaluation and generates the greatest benefit to students. The available literature suggests that supervision of the final project at master-level is a promising arena in this regard.

To sum up, the literature suggests that student enjoyment facilitates learning, but by no means guarantees it, and that supervisors can facilitate student learning in the final project in five distinct ways, by: (1) communicating well; (2) providing thorough and appropriate feedback; providing competent guidance on (3) methods and (4) theory; and (5) striking a balance between under- and over-involvement. The research questions can thus be stated as:

1. How do taught master's students at a given institution experience being supervised in their final projects, in terms of the five elements just outlined?

2. What does such experience mean for universities, given the increased significance, and expansion, of teaching ratings?

Having outlined the theoretical basis for the paper and generated the research questions, this paper now continues to explain the methods used in answering them, before presenting and discussing the results.

\section{Methods}

Answering the first research question required conducting primary research into students' experience. Addressing the second means analysing teaching evaluations in light of the Teaching Excellence Framework. This section concentrates on the primary research undertaken, in the form of questionnaire and focus groups.

In keeping with Bunderson and Thompson's (2009) method of generating exploratory 
data, the researchers developed a questionnaire (see Appendix 1) to capture student perceptions of each of the five specific aspects of supervision identified, and included open-ended narrative questions, to capture views on possible improvements to supervision arrangements. The survey was prepared in consultation with BusinessCollege's Educational Development Unit, and research was conducted strictly according to the standards and guidance in place at the time, including gaining the requisite ethical approval. The study aimed to develop an initial understanding of the student dissertation supervision experience. Given the small window of opportunity for data gathering (a summer project submitted at the very end of the degree programme), and the strongly international nature of the student population, it was important to keep the survey as concise and straightforward as possible. In the interests of saliency and consistency, a 5-point Likert scale was used with polar opposite ends and a neutral mid-point. Question 1, 'How balanced was your supervisor?', related to supervisor involvement. Question 2 inquired about supervisor availability, and the third question invited a rating of the usefulness of supervisor feedback. Questions 4 and 5 elucidated usefulness ratings for methods and theory guidance. The final open-ended question invited participants to identify a change recommendation that could have improved the supervisory experience. Two additional open text boxes invited master's students to offer up any additional comments or suggestions.

The questionnaire was administered on the same day as students submitted their final projects. To encourage participation in the data-gathering process, paper questionnaires and tablet computers were available at BusinessCollege's reception and its administration office. Administrative staff facilitated the process, actively encouraging students to complete the survey, whilst emphasising the voluntary nature of participation. Students wishing to enter the prize draw did so via a separate, clearly marked collection box (prize-entry was not permitted for electronic submissions, to preserve anonymity). A suitable prize was offered to incentivise participation, the draw for which took place at the end of the day.

Two fully subscribed focus groups were scheduled to take place immediately after students had submitted their work, to elicit additional information; one each in 
English and Mandarin. This was considered appropriate given the large number of Mandarin native-speakers in the cohort. However, turnout on the day led to one group being cancelled and the other becoming an individual interview. Additional focus groups were thus scheduled in a subsequent academic year. These solicited student opinions on hopes and expectations, rather than on lived experience of supervision. Both student cohorts were comparable in terms of such factors as age, academic background, and country of origin, and there were no material changes to the dissertation supervision process or policies in the intervening time. The second wave of focus groups was well subscribed. Three focus groups took place: one in Mandarin and two in English. All were subsequently transcribed for analysis. In total, nine students participated in four different events run by the lead author and a Mandarin-speaking colleague.

\section{Quantitative Results}

A total of 199 surveys were received from the outgoing 2014/2015 MSc cohort (159 on paper); a response rate of $44.2 \%$. This is within the norm for organisational research (Baruch and Holtom, 2008). Of the surveys received, 195 were complete (all numerical questions were answered) and four were partially complete. Table 1 summarises the numerical data gathered. Narrative responses to the survey are tabulated in Appendix 2.

Table 1. Descriptive statistics.

\begin{tabular}{|l|c|c|c|c|c|}
\hline & $\begin{array}{c}\text { Question 1: } \\
\text { Balance }\end{array}$ & $\begin{array}{c}\text { Question 2: } \\
\text { Communication }\end{array}$ & $\begin{array}{c}\text { Question 3: } \\
\text { Feedback }\end{array}$ & $\begin{array}{c}\text { Question 4: } \\
\text { Methodology }\end{array}$ & $\begin{array}{c}\text { Question 5: } \\
\text { Theory }\end{array}$ \\
\hline Average & -0.1744 & 3.7949 & 3.9333 & 3.7897 & 3.5795 \\
\hline $\begin{array}{l}\text { Standard } \\
\text { deviation }\end{array}$ & 0.8375 & 1.0300 & 0.8855 & 0.9316 & 1.1566 \\
\hline Median & 0 & 4 & 4 & 4 & 4 \\
\hline $\begin{array}{l}\text { Possible } \\
\text { range }\end{array}$ & $\begin{array}{c}\text { Scoring range: } \\
\text {-2 (far too } \\
\text { involved) } \\
+2 \text { (far too } \\
\text { uninvolved) }\end{array}$ & \multicolumn{4}{|c}{$\begin{array}{c}\text { Scoring range: } \\
\text { (not well/useful at all) } \\
\text { (extremely well/useful) }\end{array}$} \\
\hline
\end{tabular}


Contingency tables, also called cross-tabs, generated using the statistical analysis package SPSS, were used to identify interactions between different responses. Question 1 was re-scored, so that it was in line with the values in other questions. Thus, -2 became 1, 0 became 3, and 2 became 5. Goodman and Kruskal's gamma was used to determine associations between the different questions amongst the 199 respondents. There were statistically significant moderate-to-strong correlations between all questions. All items had a statistically significant relation to one another (at a confidence level of $p \leq 0.002$ ). Questions 2-5 were positively correlated to one another. The strength of this relationship ranged from moderate $(G=0.408)$ to strong $(\mathrm{G}=0.775)$. Responses to Question 1 were negatively correlated with the other four questions, the strength of this relationship ranging from weak $(\mathrm{G}=0.330)$ to fairly strong $(\mathrm{G}=0.635)$. Figure 1 summarises the cross-tab data in bar-chart form, providing the strength and direction of the relationship between each pair, together with the level of significance test. Analysis in the next section focuses on the strength and direction of these correlations.

Figure 1. Summary of cross-tab data: relationship between questions. 


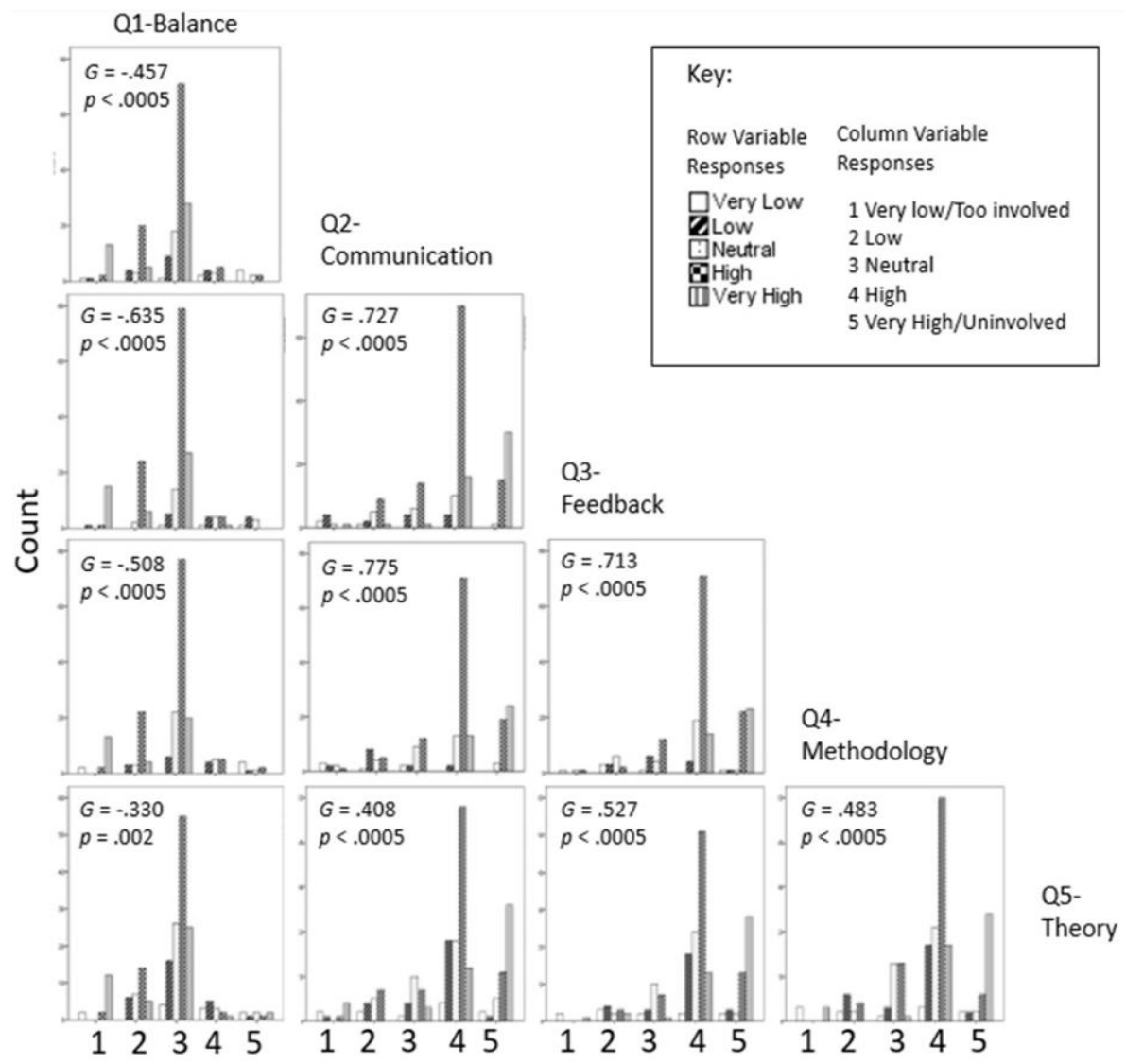

\section{Qualitative Findings}

This section sets out a discussion of the findings from the four focus groups and the information included in the open-ended questions in the survey. Much of the discussion indicated a lack of awareness of the process and of the role of supervisors (and their responsibilities), leading to uncertainty and unrealistic expectations. This was particularly pronounced for the Mandarin-language focus group, but was a point of similarity for all students.

There were clear differences between the Mandarin and English language focus groups. English-language responders wanted supervisors to be interested in students' work and be supportive and responsive to their needs; notably to put greater focus on the 'affiliation' variable (see de Kleijn et al., 2012). This preference corresponds with Marshall's waiter model (2009, pp.150, 156-157), in which the 
supervisor is on hand when needed, but otherwise leaves the student to get on with it unhindered. In this model, supervising is more about facilitating than teaching, as the following focus group extract indicates:

English-language3: I would say for me, to show interest in what I am trying to get out of the dissertation, to try to at least be positive and give me trust and confidence in what I am doing. That's at least what I am hoping for from a supervisor.

English-language2: It's kind of a mix of all these things, just the attention or engagement, not just ignoring what you say, to have some interest in you . . . I wouldn't expect them to be super involved because I mean, because it's supposed to be your project. I don't expect much more than guidance really.

English-language1: If I really, really had to choose I would choose 'too involved' than 'not enough'.

Mandarin-language respondents, by contrast, wanted more active guidance from supervisors. To build on Marshall's (2009) gastronomical theme: if English-language respondents preferred the waiter model, then Mandarin-language respondents were looking for a cooking-class arrangement. That is, they wanted a mix between teaching and facilitating, with more frequent interventions and the occasional demonstration, and strong guidance on the structure of their work (i.e. greater focus on the 'control' variable: see de Kleijn et al., 2012; Khalifa, 2018). They appeared to want supervisors to take the lead, as the following Mandarin language focus group extract illustrates;

Mandarin-language1: For me, the most important [thing] is the structure of the [final project]. We wish supervisors would give us feedback on the structure in details, so we can start working on each part of the dissertation. 
Mandarin-language2: Also, we may focus writing on some parts which are not actually important to the research question. We are afraid of deviating from the main theme ... We hope the supervisors could suggest us which area to focus.

Mandarin-language1: That would be good [the supervisor giving students a reading list].

Mandarin-language 2, 3, 4: Yeah, that would be good if we are given that. Yeah. Agree.

Mandarin-language1: We are afraid that some supervisors just say you should look for related literature by yourself. But there are so many resources. We don't know which ones are good. It would be great if they could give us a list of literature to read.

Analysis of the focus group findings largely confirms the limited previous work in this area (e.g., de Kleijn et al., 2012; 2013). However, they provide additional insight, particularly in the UK context and on the international dimension. The next section discusses the findings in some detail.

\section{Discussion}

The paper started with a review of relevant literature on supervision and student evaluation, then introduced the methods used to conduct the research, the findings of which have just been presented. This discussion section now offers an interpretation of the data gathered and concludes by addressing the limitations of the study.

The focus group data suggested that students of all backgrounds are often unsure of what to expect from the final project, and that there are notable differences between 
students, depending on their background. It is unsurprising that some international students desire more active guidance from their supervisors. This arguably reflects the uncertainty associated with their comparative lack of experience in independent study and unfamiliarity with the academic norms of a different culture, including ways of reasoning (see: Harwood and Petrić, 2019; Zheng, et al., 2019). As one respondent put it, '[P]robably half the students, they don't have experience studying abroad so I think they don't know how to write a proposal, how to write a dissertation, even, some of the people, they don't know how to write essays.' Such an analysis is congruent with a recent study of international students in the UK that calls for critical thinking - typically considered the 'gold standard' of Western higher education - to be reconsidered (Hammersley-Fletcher and Hanley, 2016).

The clear differences in expectations between different groups of students arguably provides strong support for the dyadic model of supervision, which by its nature allows for more individually-tailored interaction (Wisker, 2012). However, it is relevant to note that BusinessCollege students were aware that their supervisor plays an influential role in grading their work, and as the primary source for employment references. In such an exposed, power-influence context, it is likely that some students might find it difficult to openly share their honest opinions and issues, even when given the opportunity in an anonymous feedback process.

By comparison to the focus groups, the survey asked about students' experience of having been supervised. The data indicate a negative correlation between Question 1 (perceived supervisor involvement) and the other numerical questions (other aspects of the supervision experience). Ceteris paribus, this suggests that overinvolved supervisors were seen to provide more useful guidance. This is supported both by narrative responses to survey Question 6 (on possible improvements: students expressed more dissatisfaction with under-involved than with over-involved supervisors), and by views in the English-language focus group.

This makes sense given the importance of the final project and the student-asconsumer phenomenon. The implication is that supervisors should err on the side of over-involvement, leading supervisees with stronger guidance à la cooking class 
metaphor, rather than waiting in the background to be called upon when needed. However, such an interpretation should be treated cautiously, for three key reasons. First, Question 1 scoring was not linear: the 'ideal' score for that question was 3; not 1 or 5 . Second, the descriptive statistics (Table 1) indicate that students perceived their supervisors to have already achieved a near-perfect balance between the two extremes of being over-involved and insufficiently supportive, with the lowest variance in responses. Interestingly, this is despite focus group indication that different groups of students have very different preferences upon entering the process, suggesting that students' views change during the final project process, and/or they perceived their supervisors as getting the balance right for them. Third, although the dyadic supervisory relationship is shorn of many of the factors that reduce the value of student evaluations, the score could nonetheless be at least partially an artefact of students valuing form over content (see Naftulin et al., 1973 the Dr Fox effect).

Responses to Question 5 (theory) had the weakest relationships with other questions, with only moderate correlations. Question 5 also had the lowest mean score of the four linear questions, and the highest standard deviation. This arguably reflects the non-specialist nature of supervision and represents an area with particular potential for improvement. It is reasonable to assume that students whose supervisors' expertise matches their own research areas are more likely to feel well served on theory; a view supported by the strong correlations in students' responses to Questions 2-4 (communication, feedback, and methodology). Interestingly, evidence from the focus groups suggests limited student expectation of theoretical guidance at the outset.

To sum up: survey respondents generally evaluated their experience positively, perceiving their supervisors to have struck a good balance between over- and underinvolvement, a key factor identified by Wisker (2012). Even those who were less satisfied with other aspects of their supervision experience tended to be happy with their supervisors' involvement. Students feel better guided when their supervisor is an expert in their subject area; nonetheless, supervisor engagement can compensate for lack of subject expertise. Overall, we can expect student satisfaction 
in final project supervision to map well with learning satisfaction (Gibson, 2010; and see earlier), and student satisfaction with supervision to be positively correlated with learning. These results represent good grounds for optimism about the introduction of teaching evaluation for master's final project supervision. Indeed, the present research suggests that student evaluation of supervision has the potential to lead to improved teaching scores, without threatening teaching quality. Moreover, the pernicious reciprocity effect between faculty and students outlined earlier (and see Clayson et al., 2006) is less salient in a final project, because of the nature of the exercise. In short, therefore, the evidence suggests that paying attention to the student experience in supervision may be a relatively easy way for universities to both improve student learning and raise teaching scores. There is therefore a good argument to be made for timely investment in staff and processes around the final project.

BusinessCollege provides an intriguing exploratory case study. Nonetheless, the findings are arguably relevant to practice in other business and/or management schools, and indeed, to the wider higher education environment (HESA, 2019).

This discussion section concludes by addressing the limitations of the current research. The focus groups were conducted with small numbers, and results should be seen in that light. In terms of questionnaire design, Questions 2-5 were scored differently from Question 1, making direct comparisons and interpretation of the data more challenging. This is mitigated somewhat by the simplicity of the exploratory survey, which was intended to capture students' views on a limited number of questions. Although the response rate was good by many measures, respondents were self-selecting. It was thus not random and cannot be considered representative. The results, therefore, need to be treated with caution. Nonetheless, the proportion of the student population completing the questionnaire is large enough to be relevant for practice. Perhaps the $44 \%$ who responded were the most motivated to do so, in which case they arguably represent both extremes of feeling. Also, given the differences between the focus groups, future iterations of the survey might capture such additional demographic information as students' home language. Finally, the results presented here must be treated as indicative, in keeping with 
exploratory research. A larger sample would have been needed to test construct validity, and reliability testing would have required a substantially greater sample. Having said that, no claim to validity and reliability is being made: validating the questionnaire would have been beyond the stated scope of the research.

\section{Conclusions}

This paper has examined the literature relevant to the supervision of master's final projects, a research area that appears to be underdeveloped. It has addressed challenges related to the student evaluation of teaching. A salient survey instrument was developed using a pragmatic methodology. The results of that survey have been presented and discussed, drawing several significant conclusions. The results suggest that a greater focus on the student experience in supervision may be a relatively easy way for universities both to improve student learning and to raise teaching scores, without compromising teaching quality. The paper now concludes with several suggestions each for practice and research, before ending with a final reflection.

The present research has numerous practical pedagogic implications for institutions. This is timely given the increasing regulatory focus (e.g. TEF) being given to the postgraduate student experience. First, the importance of feedback for students suggests that final project supervisors should be required to receive specific training on supervision and/or giving feedback. This implication is supported by Harwood and Petrić's (2019) reporting on pedagogical activities to promote supervisory practice.

Second, institutions should carefully consider the optimal number of students that an individual faculty member may simultaneously supervise, taking into account both aptitude and motivation, with a goal of improving both student and staff satisfaction before the TEF is expanded to postgraduate students. 
Third, the research supports previous literature studies (Holdaway, 1995; Drennan and Clarke, 2009; Roberts and Seaman, 2018) suggesting that it is beneficial to match supervisors' expertise with students' research choices: institutions should do so where possible, particularly in the case of students from non-Western backgrounds. However, the data suggests that this aspect is neither decisive in meeting students' expectations nor in mediating their experience of the process.

Penultimately, the focus group data and narrative feedback from the surveys indicate some appetite for modified administrative arrangements at BusinessCollege, particularly in providing greater clarity on processes and procedures (such as frequency of meeting, and commenting on written drafts).

Finally, universities might usefully consider following the example of many UK local councils, by providing summary information on the processes to follow in preparing and submitting work in the native languages most frequently spoken by their students. Doing so would facilitate non-native students' understanding of unfamiliar academic practices and permit them to focus more fully on the quality of their academic work.

The exploratory research presented here suggests numerous directions for further research. The present research has been strengthened by serendipity in failure: conducting research on both pre-dissertation and post-dissertation students provided data from two points along students' progress, which, although not originally planned, has strengthened the findings and analysis. Can the scope be usefully widened further, to draw out expectations, needs and wants before, during and after the dissertation experience? Can it be broadened to also include undergraduate dissertations?

The second area is one of differences. As is common across the Western higher education landscape (Universities UK, 2014; Australian Government, 2016), BusinessCollege has a high proportion of international students, particularly from China. To what extent do learning cultures embedded in specific educational backgrounds influence students' expectations of the final project and of the 
supervisor? What role does an international faculty play in the context of supervision?

One implication of this paper is that students' experience of the final project could disproportionately affect their ongoing perceptions of BusinessCollege, affecting organizational reputation. The third area of further research would thus be to test this possibility through a survey of alumni at some temporal distance from completing their studies.

The fourth avenue of inquiry is related to the implication that student satisfaction with the supervision process is more closely related to learning than is student satisfaction with coursework. There are good theoretical reasons for such a conclusion (Erichsen, et al., 2014; Roberts and Seaman, 2018) but can it be empirically tested? Also, what about alternative models of supervision?

Finally, the possibilities of experiential learning are interesting. Students' final piece of work is typically a stand-alone research project. An ongoing discussion about the value of experiential learning (e.g. Chia and Holt, 2008; Ng, et al., 2009) suggests that alternative forms of final assessment - such as internships (Beenen, 2013) - may be worth exploring.

In closing, master's students are the least well-understood student group, and the final project is even less well-understood. Universities arguably have a shrinking window of opportunity to experiment; to conduct well-monitored trials of different ways of supervision and other aspects of teaching at master's level. Doing so could both improve students' learning and experience, and benefit university ratings.

\section{Acknowledgements}

The authors thank the Education Development unit and colleagues at BusinessCollege for their input at various stages of this paper's development. Thanks are due also to BusinessCollege for providing financial and organizational 
support with the data gathering, as well as to Eli Grant for assistance with data analysis.

\section{References}

Anderson, C., Day, K., and McLaughlin, P. (2006) 'Mastering the dissertation: lecturers' representations of the purposes and processes of Master's level dissertation supervision', Studies in Higher Education, 31(2), pp. 149-168.

Andrews, M., Brown, R., and Mesher, L. (2018) 'Engaging students with assessment and feedback: improving satisfaction and attainment with students as codesigners', Practitioner Research in Higher Education, 11(1), pp. 32-46.

Australian Government, Department of Education and Training (2016) International student numbers 2015. Research Snapshot Available at: https://internationaleducation.gov.au/research/ResearchSnapshots/Documents/Student Numbers 2015.pdf

Baruch, Y., and Holtom, B. C. (2008) 'Survey response rate levels and trends in organizational research', Human Relations, 61(8), pp. 1139-1160.

Beatty, J. E., and Leigh, J. S. A. (2010) 'Taking stock of management education: A comparison of three management education journals', Journal of Management Education, 34(3), pp. 367-392.

Beenen, G. (2013) 'The effects of goal orientations and supervisor concerns on MBA intern learning and performance', Academy of Management Learning and Education, 13(1), pp. 82-101.

Billsberry, J. (2014) 'The rise and rise of management edutainment', Journal of Management Education, 38(2), pp. 151-159. 
BIS (2015) 'Fulfilling our potential: Teaching excellence, social mobility and student choice', London: Department for Business, Innovation and Skills. Available at: https://www.gov.uk/government/consultations/higher-educationteaching-excellence-social-mobility-and-student-choice (Accessed: 25 March 2017).

BIS (2016) Success as a Knowledge Economy: Teaching Excellence, Social Mobility and Student Choice. London: Department for Business, Innovation and Skills. Available at:

https://www.gov.uk/government/uploads/system/uploads/attachment_data/f ile/523396/bis-16-265-success-as-a-knowledge-economy.pdf (Accessed: 25 April 2018).

Blackmore, J. (2009) 'Academic pedagogies, quality logics and performative universities: Evaluating teaching and what students want', Studies in Higher Education, 34(8), pp. 857-872.

Blackwood, T. (2012) 'Business undergraduates' knowledge monitoring accuracy: how much do they know about how much they know?' Teaching in Higher Education, 18(1), pp. 1-13.

Bunderson, J. S., and Thompson, J. A. (2009) 'The call of the wild: zookeepers, callings, and the double-edged sword of deeply meaningful work', Administrative Science Quarterly, 54(1), pp. 32-57.

Chia, R., and Holt, R. (2008) 'The nature of knowledge in business schools', Academy of Management Learning and Education, 7(4), pp. 471-486.

Clayson, D. E., Frost, T. F., and Sheffet, M. J. (2006) 'Grades and the student evaluation of instruction: A test of the reciprocity effect', Academy Of Management Learning and Education, 5(1), pp. 52-65. 
Del Río, M. L., Díaz-Vázquez, R., and Maside Sanfiz, J. M. (2018) 'Satisfaction with the supervision of undergraduate dissertations', Active Learning in Higher Education, 19(2), 159-172.

de Kleijn, R. A. M., Mainhard, M. T., Meijer, P. C., Brekelmans, M., and Pilot, A. (2013) 'Master's thesis projects: student perceptions of supervisor feedback', Assessment and Evaluation in Higher Education, 38 (March 2015), pp. 1012-1026.

de Kleijn, R. A. M., Mainhard, M. T., Meijer, P. C., Pilot, A., and Brekelmans, M. (2012) 'Master's thesis supervision: relations between perceptions of the supervisor-student relationship, final grade, perceived supervisor contribution to learning and student satisfaction', Studies in Higher Education, 37(8), pp. 925-939.

de Kleijn, R. A. M., Meijer, P. C., Brekelmans, M., and Pilot, A. (2014) 'Adaptive research supervision: exploring expert thesis supervisors' practical knowledge', Higher Education Research and Development, (August 2014), pp. 1-14.

de Kleijn, R. A. M., Meijer, P. C., Pilot, A., and Brekelmans, M. (2014) 'The relation between feedback perceptions and the supervisor-student relationship in master's thesis projects', Teaching in Higher Education, 19(4), pp. 336-349.

Dericks, G., Thompson, E., Roberts, M., and Phua, F. (2019) 'Determinants of PhD student satisfaction: The roles of supervisor, department, and peer qualities', Assessment and Evaluation in Higher Education, 44(7), pp. 1046-1061.

Dietz, C., Arkenau, C., and Meyer-Wentrup, F. (2000) 'The German Medical Dissertation - Time to Change?' Academic Medicine. 75(8), pp. 861-863

Douglas, J., Douglas, A., and Barnes, B. (2006) 'Measuring student satisfaction at a Journal of Learning Development in Higher Education, Issue 16: December 2019 
UK university', Quality Assurance in Education, 14(3), pp. 251-267.

Drennan, J., and Clarke, M. (2009) 'Coursework master's programmes: the student's experience of research and research supervision', Studies in Higher Education, 34(5), pp. 483-500.

Dysthe, O. (2002) 'Professors as mediators of academic text cultures: An interview study with advisors and master's degree students in three disciplines in a Norwegian University', Written Communication, 19(4), 493-544.

Dysthe, O., Samara, A., and Westrheim, K. (2006) 'Multivoiced supervision of Master's students: a case study of alternative supervision practices in higher education', Studies in Higher Education, 31(3), pp. 299-318.

Eaton, S. E., and Penaluna, L. A. (2019) Grading with integrity: Opening the uncomfortable conversation around grade inflation. [accessed from https://prism.ucalgary.ca/handle/1880/110055 28 July 2019]

Ebadi, S. and Pourahmadi, F. (2019) 'Exploring Challenges in Writing EFL Master Theses: Students and Supervisors' Perspectives', i-Manager's Journal on English Language Teaching, 9(2), 42.

Egan, R., Stockley, D., Brouwer, B., Tripp, D., and Stechyson, N. (2009) 'Relationships between area of academic concentration, supervisory style, student needs and best practices', Studies in Higher Education, 34(3), pp. 337-345.

Erichsen, E. A., Bolliger, D. U., and Halupa, C. (2014) Student satisfaction with graduate supervision in doctoral programs primarily delivered in distance education settings. Studies in Higher education, 39(2), 321-338.

Filippou, K., Kallo, J., and Mikkilä-Erdmann, M. (2017) 'Students' views on thesis supervision in international master's degree programmes in Finnish 
universities', Intercultural Education 28 (3), 334-352. DOI:

$10.1080 / 14675986.2017 .1333713$

Finney, T. G., and Finney, R. Z. (2010) 'Are students their universities' customers? An exploratory study', Education + Training, 52(4), pp. 276-291.

Gibson, A. (2010) 'Measuring business student satisfaction: a review and summary of the major predictors', Journal of Higher Education Policy and Management, 32(3), pp. 251-259.

Gunn, A. (2018) 'Metrics and methodologies for measuring teaching quality in higher education: developing the Teaching Excellence Framework (TEF)', Educational Review, 70(2), 129-148.

Hallett, F. (2010) 'The postgraduate student experience of study support: a phenomenographic analysis', Studies in Higher Education, 35(2), 225-238.

Halse, C. (2011) "Becoming a supervisor': the impact of doctoral supervision on supervisors' learning', Studies in Higher Education, 36(5), pp. 557-570.

Halse, C., and Malfroy, J. (2010) 'Retheorizing doctoral supervision as professional work', Studies in Higher Education, 35(1), pp. 79-92.

Hammersley-Fletcher, L., and Hanley, C. (2016) 'The use of critical thinking in higher education in relation to the international student: Shifting policy and practice', British Educational Research Journal, 42(6), pp. 978-992.

Harwood, N., and Petrić, B. (2018) 'Adaptive master's dissertation supervision: a longitudinal case study', Teaching in Higher Education, $0(0)$, pp. 1-16. https://doi.org/10.1080/13562517.2018.1541881

Harwood, N., and Petrić, B. (2019) 'Helping International Master's Students Navigate Dissertation Supervision: Research-Informed Discussion and AwarenessRaising Activities', Journal of International Studies, 9(1), pp. 150-171. 
HESA (2019) What do HE students study? [ accessed 11 April 2019 https://www.hesa.ac.uk/data-and-analysis/students/what-study ]

Holdaway, E. (1995) Supervision of Graduate Students. Canadian Journal of Higher Education, 25(3), pp. 1-29.

Holland, E. P. (2019) 'Making sense of module feedback: accounting for individual behaviours in student evaluations of teaching', Assessment and Evaluation in Higher Education, 44(6), pp. 961-972.

Holtbrügge, D., and Mohr, A. T. (2010) 'Cultural Determinants of Learning Style Preferences', Academy of Management Learning and Education, 9(4), pp. 622-637.

Hordern, J. (2014) 'Management studies educational knowledge: technical, elite or political?' Teaching in Higher Education, 19(4), pp. 385-396.

Khalifa, R. (2018) 'The Presence and Efficacy of Supervision Styles: A case study of a Professional Doctoral Progamme in the United Arab Emirates (UAE)'. Journal of International Business Eductation. Volume 13: pp:00-00 online

Kruger, J., and Dunning, D. (1999) 'Unskilled and unaware of it: How difficulties in recognizing one's own incompetence lead to inflated self-assessments', Journal of Personality and Social Psychology, 77(6), pp. 1121-1134.

Lancaster, T., and Fanshawe, T. R. (2015) 'Assessing the quality of UK medical schools: what is the validity of student satisfaction ratings as an outcome measure?' [Accessed from https://weblearn.ox.ac.uk/access/content/group/895746d8-7afb-4cb3-a461$7 \mathrm{e} 7 \mathrm{fca} 72 \mathrm{e} 67 \mathrm{c} /$ Validity of student satisfaction ratings as a quality metric in UK medical education.pdf 25 August 2018] 
Larivière, V., Zuccala, A., and Archambault, É. (2008) 'The declining scientific impact of theses: Implications for electronic thesis and dissertation repositories and graduate studies', Scientometrics, 74(1), pp.109-121.

Marshall, S. (2009) 'Supervising projects and dissertations', In H. Fry, S. Ketteridge, and S. Marshall (Eds.), A handbook for teaching and learning in higher education: Enhancing academic practice (3rd ed.). London: Routledge.

McCallin, A., and Nayar, S. (2012) 'Postgraduate research supervision: a critical review of current practice', Teaching in Higher Education, 17(1), pp. 63-74. http://doi.org/10.1080/13562517.2011.590979

Meeus, W., Van Looy, L., and Libotton, A. (2004) 'The Bachelor's thesis in teacher education', European Journal of Teacher Education, 27(3), pp. 299-321.

Morris, S., Pitt, R., and Manathunga, C. (2012) 'Students' experiences of supervision in academic and industry settings: results of an Australian study', Assessment and Evaluation in Higher Education, 37(5), 619-636.

Naftulin, D. H., Ware, J. E. J., and Donnelly, F. A. (1973) 'The Doctor Fox lecture: A paradigm of educational seduction', Journal of Medical Education, 48(7), pp. 630-635.

Naidoo, D. (2015) 'Understanding non-traditional PhD students habitus - implications for PhD programmes', Teaching in Higher Education, 20(3), pp. 340-351.

Ng, K. Y., Dyne, L. Van, and Ang, S. (2009) 'From experience to experiential learning: Cultural intelligence as a learning capability for global leader development', Academy of Management Learning and Education, 8(4), pp. 511-526.

Nicholls, J. (2019) 'Higher education governance and policy on trial', Governing Higher Education Today: International Perspectives, 47 in John, R., 
Nicholls, J., and Strike, T. (Eds.). (2019). Governing Higher Education

Today: International Perspectives. Routledge.

OfS (2018) 'New Office for Students research to focus on value for money', News Release, 23 January 2018. Bristol: Office for Students. [Accessed from https://www.officeforstudents.org.uk/new-office-for-students-research-tofocus-on-value-for-money/ 25 April 2018]

Paolini, A. (2015) 'Enhancing teaching effectiveness and student learning outcomes', The Journal of Effective Teaching, 15(1), 20-33. Retrieved from http://search.ebscohost.com/login. aspx?direct=trueanddb=eueandAN=102 152590andsite=ehost-liveandscope $=$ site

Parker-Jenkins, M. (2018) 'Mind the gap: developing the roles, expectations and boundaries in the doctoral supervisor-supervisee relationship', Studies in Higher Education, 43(1), 57-71.

Petty, G. (2009) Teaching today: A practical guide (4th ed.). Bath: NelsonThornes.

Pilcher, N. (2011) 'The UK postgraduate Masters dissertation: an 'elusive chameleon'?', Teaching in Higher Education, 16(1), 29-40.

Reguant, M., Martínez-Olmo, F., and Contreras-Higuera, W. (2018) 'Supervisors' perceptions of research competencies in the final-year project', Educational Research, 60(1), 113-129.

Remedios, R., and Lieberman, D. A. (2008) 'Editorial. I liked your course because you taught me well: The influence of grades, workload, expectations and goals on students' evaluations of teaching', British Educational Research Journal, 34(1), pp. 91-115.

Roberts, L. D., and Seaman, K. (2018) 'Good undergraduate dissertation supervision: perspectives of supervisors and dissertation 
coordinators', International Journal for Academic Development, 23(1), 2840 .

Rowley, J., and Slack, F. (2004) 'What is the future for undergraduate dissertations?' Education+ Training, 46(4), pp. 176-181.

Simpson, R., Sturges, J., and Weight, P. (2010) 'Transient, unsettling and creative space: Experiences of liminality through the accounts of Chinese students on a UK-based MBA', Management Learning, 41(1), pp. 53-70.

Todd, M., Bannister, P., and Clegg, S. (2004) 'Independent inquiry and the undergraduate dissertation: Perceptions and experiences of final-year social science students', Assessment and Evaluation in Higher Education 29(3): 335-55.

Tomlinson, M. (2018) 'Conceptions of the value of higher education in a measured market', Higher Education, 75(4), 711-727.

Universities UK. (2014) 'The funding environment for universities 2014. International students in higher education: The UK and its competition', Higher Education in Focus. Retrieved from http://www.universitiesuk.ac.uk/policyand-analysis/reports/Documents/2014/international-students-in-highereducation.pdf

Unsworth, K. L., Turner, N., Williams, H. M., and Piccin-Houle, S. (2010) 'Giving thanks: the relational context of gratitude in postgraduate supervision', Studies in Higher Education, 35(8), pp. 871-888.

Uttl, B., White, C. A., and Gonzalez, D. W. (2017) 'Meta-analysis of faculty's teaching effectiveness: Student evaluation of teaching ratings and student learning are not related', Studies in Educational Evaluation, 54, pp. 22-42. 
Vos, L., and Armstrong, K. (2019) 'Context and process challenges associated with supervising postgraduate dissertations: An example from marketing', The International Journal of Management Education, 17(1), 47-61.

Wiltbank, L., Williams, K., Salter, R., Marciniak, L., Sederstrom, E., McConnell, M., Offerdahl, E., Boyer, J., and Momsen, J. (2019) 'Student perceptions and use of feedback during active learning: a new model from repeated stimulated recall interviews', Assessment and Evaluation in Higher Education, 44(3), 431-448.

Wisker, G. (2012) The good supervisor: Supervising postgraduate and undergraduate research for doctoral theses and dissertations. $2^{\text {nd }} \mathrm{Ed}$. Palgrave Macmillan, London.

Yusoff, M., McLeay, F., and Woodruffe-Buron, H. (2015) 'Dimensions driving business student satisfaction in higher education', Quality Assurance in Education, 23(1), 86-104.

Zabaleta, F. (2007) 'The use and misuse of student evaluations of teaching', Teaching in Higher Education, 12(1), pp. 55-76.

Zheng, Y., Yu, S., Wang, B., and Zhang, Y. (2019) 'Exploring student engagement with supervisor feedback on master's thesis: Insights from a case study', Innovations in Education and Teaching International, 1-12.

\section{Author Details}

Stephanos Anastasiadis is Professor at the Police Academy of Lower Saxony, Germany. Whilst preparing this manuscript, he was Senior Lecturer in Organisations and Sustainability at Royal Holloway, University of London, where he taught 
business ethics and sustainability. His research interests centre on the responsible use of organizational power. He previously worked as an environmental lobbyist in Brussels. Stephanos has published in outlets such as the British Journal of Management, Journal of Management Inquiry and Business \& Society.

Justin O'Brien is Senior Lecturer in Strategy and Marketing and a National Teaching Fellow. He is Director of Undergraduate Education and teaches digital, services and entrepreneurial marketing, adding design thinking most recently to his portfolio. He publishes on practical, often experiential, pedagogic interventions and business case studies. He teaches internationally in Stockholm, Paris, Toulouse and Singapore. 


\section{Appendix 1: Questionnaire}

[The original questionnaire was on BusinessCollege letterhead]

Thank you for taking the time to complete this anonymous survey about your experience of being supervised during your [final project]. Your answers will help us to understand how we are performing, and to identify areas in which we can improve the quality of the supervision we offer. It should take 3-5 minutes to answer all seven questions.

Completing the questionnaire in person at [institution] entitles you to enter a lucky draw for one of two prizes. Each prize is $£ 150$-worth of vouchers to [an iconic local store]. After you complete the questionnaire you will be offered a paper token: if you want to enter the draw, complete the token and put it in the box. Prizes will be drawn at random on 1 September, and the winners informed the same day.

\section{Questions}

\section{Balance}

The supervisor's role is to provide assistance to the student, striking a balance between being too involved in the student's work and not providing enough necessary support.

How balanced was your supervisor? (choose one option only)

\begin{tabular}{|c|c|c|c|c|}
\hline $\begin{array}{c}\text { Far too } \\
\text { involved }\end{array}$ & Too involved & $\begin{array}{c}\text { Balance about } \\
\text { right }\end{array}$ & $\begin{array}{c}\text { Too little } \\
\text { support }\end{array}$ & $\begin{array}{c}\text { Far too little } \\
\text { support }\end{array}$ \\
\hline$\square$ & $\square$ & $\square$ & $\square$ & $\square$ \\
\hline
\end{tabular}

\section{Communication}

Supervisor and student should communicate about the project as appropriate.

How well do you think your supervisor's availability matched your needs? (choose one option only)

\begin{tabular}{|c|c|c|c|c|}
\hline Not well at all & $\begin{array}{c}\text { Not particularly } \\
\text { well }\end{array}$ & $\begin{array}{c}\text { Neither well nor } \\
\text { badly }\end{array}$ & Well & Extremely well \\
\hline$\square$ & $\square$ & $\square$ & $\square$ & $\square$ \\
\hline
\end{tabular}




\section{Feedback}

Feedback from the supervisor should help the student to develop new insights and improve their work.

How useful did you find your supervisor's feedback in general? (choose one option only)

\begin{tabular}{|c|c|c|c|c|}
\hline $\begin{array}{c}\text { Extremely } \\
\text { useful }\end{array}$ & Useful & $\begin{array}{c}\text { Neither useful } \\
\text { nor not useful }\end{array}$ & $\begin{array}{c}\text { Not particularly } \\
\text { useful }\end{array}$ & $\begin{array}{c}\text { Not useful at } \\
\text { all }\end{array}$ \\
\hline$\square$ & $\square$ & $\square$ & $\square$ & $\square$ \\
\hline
\end{tabular}

\section{Methodology}

One of the main areas in which a supervisor can help a student is to provide guidance on research methods.

How useful was your supervisor's guidance on methods? (choose one option only)

\begin{tabular}{|c|c|c|c|c|}
\hline $\begin{array}{c}\text { Not useful at } \\
\text { all }\end{array}$ & $\begin{array}{c}\text { Not particularly } \\
\text { useful }\end{array}$ & $\begin{array}{c}\text { Neither useful } \\
\text { nor not useful }\end{array}$ & Useful & $\begin{array}{c}\text { Extremely } \\
\text { useful }\end{array}$ \\
\hline$\square$ & $\square$ & $\square$ & $\square$ & $\square$ \\
\hline
\end{tabular}

\section{Theory}

Another main area in which a supervisor can help a student is to provide guidance on theoretical development.

How useful was your supervisor's guidance on theory? (choose one option only)

\begin{tabular}{|c|c|c|c|c|}
\hline $\begin{array}{c}\text { Extremely } \\
\text { useful }\end{array}$ & Useful & $\begin{array}{c}\text { Neither useful } \\
\text { nor not useful }\end{array}$ & $\begin{array}{c}\text { Not particularly } \\
\text { useful }\end{array}$ & $\begin{array}{c}\text { Not useful at } \\
\text { all }\end{array}$ \\
\hline$\square$ & $\square$ & $\square$ & $\square$ & $\square$ \\
\hline
\end{tabular}

Please suggest one change that your supervisor could have made to improve your experience. 
If you have any further comments or suggestions, please list them below.

Space for additional comments

Please place your completed questionnaire into one of the marked boxes provided. If you have any questions about this survey, please contact [named person, with details] Thank you! 


\section{Appendix 2: Narrative responses to survey}

Table 2. Areas of student concern (narrative responses to Q6 \& Q7 of questionnaire).

\begin{tabular}{|c|c|}
\hline Theme & Examples of student responses \\
\hline Feedback & $\begin{array}{l}\text { - Be a bit more specific sometimes. I felt that the feedback was } \\
\text { - } \text { too broad and could have been more focused at times. } \\
\text { the appropriateness of the methodology and literature review } \\
\text { - A bit more insight, comments and suggestions on the content } \\
\text { of the paper and theories. } \\
\text { - Advice more on discussion part } \\
\text { - In the meanwhile [my supervisor] can give us some } \\
\text { feedback. We can depend on the feedback to modify our } \\
\text { dissertation. }\end{array}$ \\
\hline Availability & $\begin{array}{l}\text { - I think [my supervisor] was giving too many students } \\
\text { - } \quad \text { supervision } \\
\text { - } \quad \text { More meeting with students. } \\
\text { - } \text { More meetings. I only had once face-to-face meeting. } \\
\text { - I think there are inadequate number of supervisor. ... Some } \\
\text { supervisors did not seem to have time to advise or support } \\
\text { their students. I do not think it is fair for both supervisors and } \\
\text { students as compared to other department where one person } \\
\text { is assigned to supervise only a few students (less than 5) }\end{array}$ \\
\hline Compatibility & $\begin{array}{l}\text { - Match supervisor and student: Understand a bit more about } \\
\text { the topic } \\
\text { - My supervisor is not keen on my research area. . }\end{array}$ \\
\hline $\begin{array}{l}\text { Administrative/ } \\
\text { organizational } \\
\text { concerns }\end{array}$ & $\begin{array}{l}\text { What should be changed is the schedule of research } \\
\text { methods class and submission period of [the] proposal. The } \\
\text { current schedule of research method has been arranged far }\end{array}$ \\
\hline
\end{tabular}




\begin{tabular}{|l|l|}
\hline & too early during the term time. \\
- & I don't think the proposals should have been marked... I got \\
& a good grade so I am not complaining ... We had to submit \\
two proposals, one as an assignment and one is the actual \\
one but they could have been the same. It didn't make \\
sense to me.
\end{tabular}




\section{Appendix 3: Details of focus group}

Table 3. Details of focus groups.

\begin{tabular}{|l|c|l|l|}
\hline \multicolumn{1}{|c|}{ Event } & Duration & Language & \multicolumn{1}{c|}{ Participants } \\
\hline $\begin{array}{l}\text { Interview } \\
\text { 1 September 2014 }\end{array}$ & $20^{\prime} 40^{\prime \prime}$ & English & $\begin{array}{l}\text { One male; } \\
\text { not English native-speaker }\end{array}$ \\
\hline $\begin{array}{l}\text { Focus group } \\
\text { 6 February 2017 }\end{array}$ & $22^{\prime} 56^{\prime \prime}$ & English & $\begin{array}{l}\text { Two male, one female; } \\
\text { two English native-speakers, } \\
\text { one non-native speaker }\end{array}$ \\
\hline $\begin{array}{l}\text { Interview } \\
\text { 13 February 2017 }\end{array}$ & $25^{\prime} 11^{\prime \prime}$ & English & $\begin{array}{l}\text { One male; } \\
\text { Mandarin native-speaker }\end{array}$ \\
\hline $\begin{array}{l}\text { Focus group } \\
\text { 13 February 2017 }\end{array}$ & $34^{\prime} 19^{\prime \prime}$ & Mandarin & $\begin{array}{l}\text { Four female; } \\
\text { all Mandarin native-speakers }\end{array}$ \\
\hline
\end{tabular}

